\title{
Effects of livestock on guanaco Lama guanicoe density, movements and habitat selection in a forest-grassland mosaic in Tierra del Fuego, Chile
}

\author{
Claudio A. Moraga, Martín C. Funes, J. Cristóbal Pizarro \\ Cristóbal Briceño and Andrés J. Novaro
}

\begin{abstract}
Locally abundant ungulates often come into conflict with human activities. After a population collapse that reached its nadir in the 1970s, the guanaco Lama guanicoe population in Tierra del Fuego, Chile, recovered and is now in conflict with sheep ranching and commercial logging. We studied the effects of livestock density and environmental factors on guanaco abundance and spatial ecology, using seasonal counts and radio-telemetry in a private protected area (Karukinka) and neighbouring ranches in a forest-grassland mosaic in Tierra del Fuego. Guanaco density was highest in low-elevation areas with more grassland cover and little snow accumulation in winter. In lowelevation areas, guanaco density decreased with increasing livestock density. Radio-tracked guanacos exhibited a partial migration pattern: two individuals migrated seasonally, selecting grasslands and avoiding forests mainly in summer, whereas six sedentary individuals used habitats according to their availability. Migratory guanacos spent the summer in Karukinka and winter on nearby ranches. High sheep densities and poor range condition on the ranches reduce key forage resources available to guanacos and may promote use of forests by guanacos, affecting forest regeneration and increasing conflict with logging. Current guanaco harvest by loggers may fail to reduce the impact of guanacos on loggedforest regeneration if guanaco spatial ecology and sheep management are not considered. Our results provide insight into the interactions among guanacos, forests and livestock ranching, and may be used to reduce conflicts and guide conservation in the Fuegian ecosystem.
\end{abstract}

Claudio A. Moraga ${ }^{*}$ (Corresponding author), J. Cristóbal Pizarro $\dagger$ and Cristóbal Briceñoł Karukinka, Chile Program, Wildlife Conservation Society, Punta Arenas, Chile. E-mail cmoraga@ufl.edu

Martín C. Funes Patagonian and Andean Steppe Program, Wildlife Conservation Society, Junín de los Andes, Neuquén, Argentina

Andrés J. Novaro INIBIOMA-CONICET and Patagonian and Andean Steppe Program, Wildlife Conservation Society, Junín de los Andes, Neuquén, Argentina

${ }^{*}$ Current address: School of Natural Resources and Environment, and Department of Wildlife Ecology and Conservation, University of Florida, USA †Current address: Department of Environment and Resource Studies, University of Waterloo, Canada

¥Current address: Department of Preventive Medicine, Faculty of Animal and Veterinary Sciences, Universidad de Chile, La Pintana, Santiago, Chile

Received 2 November 2011. Revision requested 26 April 2012.

Accepted 14 August 2012. First published online 16 October 2014.
Keywords Camelid conservation, Chile, Lama guanicoe, livestock, partial migration, sheep ranching, sub-Antarctic forest, ungulates

\section{Introduction}

T ocally abundant ungulates often have strong effects on $\_$plant communities, sometimes leading to conflict with human activities (Graham et al., 2010; Rutherford \& Schmitz, 2010). Understanding the processes that are responsible for increases and declines in ungulate abundance, and ultimately for their ecosystem effects, is necessary to guide conservation of ungulates and their habitats (Bolger et al., 2008; Gordon, 2009; Graham et al., 2010).

The guanaco Lama guanicoe has been the only native ungulate on Tierra del Fuego Island, at the southern tip of South America, for the last 8,000 years (Sarno et al., 2001). Until large-scale colonization by Europeans and their livestock began in the late 19th century, guanacos were the main source of protein for the indigenous people, the Selk'nam, who followed the guanaco's seasonal migration between forested highlands and grassy lowlands (Bridges, 1948). The number of sheep in Chilean Tierra del Fuego peaked at 1 million in the early 190os (Martinic, 1992). The Selk'nam were driven to extinction through colonization of their land and persecution. By the mid 1970s, as a result of hunting, competition from sheep, and habitat degradation, the guanaco population had collapsed to c. 7,000 on the Chilean side of the island (Raedeke, 1979). Since then, guanaco numbers have recovered to $>60,000$ as a result of hunting restrictions and reduced sheep numbers (Skewes et al., 1999; CONAMA, 2009).

Their recovery, however, has brought guanacos into conflict with another human activity expanding in Tierra del Fuego: commercial logging of the sub-Antarctic forest. This is the forest that occurs at the highest latitude in the southern hemisphere and it is being logged, mostly for timber export, at an annual rate of c. 2,00o ha, throughout the Magallanes region (Wildlife Conservation Society, unpubl. data; Donoso \& Lara, 1996; Huber \& Markgraf, 2003). Unlike the rest of their range, where guanacos live in grasslands and shrublands (de La Tour, 1954), in Tierra del Fuego much of the population lives in the transition zone between forests and grasslands (Raedeke, 1982; CONAMA, 2009). 
Guanaco herbivory affects regeneration growth patterns of southern beeches, particularly Nothofagus pumilio (Dodds, 1997; Rebertus et al., 1997), limiting timber production (Martínez-Pastur et al., 1999; Cavieres \& Fajardo, 2005). Guanaco effects on tree growth and regeneration, however, have not been disentangled from effects of livestock and logging, and it is not clear what effect guanacos have on forest dynamics at the landscape scale (Martínez-Pastur et al., 1999; Cavieres \& Fajardo, 2005). This is a common deficiency in traditional models of ungulate herbivory interactions (Wisdom et al., 2006). Nevertheless, the Chilean government recently allowed the main timber company to begin harvesting guanacos to reduce their density and for sale of their meat.

Indirect evidence suggests that grasslands are the preferred habitat of guanacos in Tierra del Fuego but that they use forest patches because of displacement by sheep (Raedeke, 1982). At a mainland site where guanacos were sedentary, sheep were shown to exclude guanacos from grasslands through resource competition (Baldi et al., 2001, 2004). The effects of sheep ranching on guanaco density and habitat use and selection have not been studied quantitatively in the grassland-forest mosaic of Tierra del Fuego. In addition, some guanacos may still migrate seasonally between forests and grasslands (Raedeke, 1982), as a combined effect of the guanaco's habitat requirements and competition with domestic ungulates. We thus need to have a better understanding of seasonal changes in guanaco ecology and of any implications of migration for the conservation and management of the species (Berger, 2004; Bolger et al., 2008; Harris et al., 2009).

Here we assess the effects of sheep density and other environmental factors on the seasonal abundance of the guanaco and describe the species' movements and habitat selection in a forest-grassland mosaic in southern Tierra del Fuego. To do this we combine a landscape-level analysis of guanaco density patterns and a habitat-level analysis of guanaco movement patterns in a private protected area and on adjacent ranches.

\section{Study area}

Our study was conducted in southern Tierra del Fuego Island, Chile, on the eastern edge of the Karukinka private protected area and adjacent ranches used mostly for sheep grazing (Fig. 1). Karukinka has had little or no livestock grazing since 1994, and since 2004 has been managed as a protected area, with no livestock ranching, by the Wildlife Conservation Society (Saavedra et al., 2011). Monthly mean temperatures range between $-4^{\circ} \mathrm{C}$ in winter and $10^{\circ} \mathrm{C}$ in summer and mean annual precipitation is 500 $\mathrm{mm}$, with frequent snowfall during autumn and winter (Tuhkanen et al., 1999).
The area includes steppe-forest ecotone and mountain forest habitats (Pisano, 1977). Dominant plant communities include beech forests, matorral shrublands, Sphagnum bogs, meadow-upland mosaics, and steppe grasslands. Tree species include the deciduous lenga Nothofagus pumilio and ñirre Nothofagus antarctica and the evergreen coihue de Magallanes Nothofagus betuloides. Main shrub species are michay Berberis ilicifolia, calafate Berberis microphylla and romerillo Chiliotrichum diffusum. Dominant grasses are Festuca, Poa and Alopecurus (Pisano, 1977).

\section{Methods}

At the landscape scale, we studied how environmental factors and human disturbances, including sheep numbers, affect seasonal changes in guanaco density along an altitudinal gradient from low-elevation grasslands in the north, primarily on ranches, to high-elevation forests and alpine meadows in the south, mainly within Karukinka (Fig. 1, Table 1). Densities of guanacos and livestock were estimated using the line transect method (Buckland et al., 2001) by surveying 14 2-7 km transects seasonally along randomly chosen sections of all available secondary roads. Transects were surveyed from the austral spring of 2006 to the spring of 2010 ( 16 seasons in all). Surveys were conducted during daylight hours, when guanacos are active, from an open pick-up truck, with two observers standing in the bed (Baldi et al., 2001). Travelling speed was $10-30 \mathrm{~km} \mathrm{~h}^{-1}$. Distances between guanaco groups and the vehicle were recorded with a laser rangefinder, and bearing to the transect line with a compass. Guanaco and livestock densities were estimated using DISTANCE v. 6.0 (Thomas et al., 2009).

To assess vegetation cover types along transects we plotted transects on a geographical information system layer in ArcView v. 3.2 (ESRI, Redlands, USA), intersected this layer with a vegetation cover map (WCS, 2006) and estimated percentage cover of each vegetation type in a $250 \mathrm{~m}$ buffer zone around each transect. Cover types considered were grasslands (steppe, bushland mosaic, alpine), forests (deciduous and evergreen) and meadows (peat bogs, meadow-upland mosaics).

Effects of environmental and anthropogenic factors on guanaco densities were analysed using a generalized linear model (GLM) with a Poisson distribution and log-link function (Dobson, 2002). The Wald statistic was calculated to evaluate the relative effect of each independent variable. We developed a maximized generalized model for guanaco density to evaluate the overall effect of each independent variable. The independent variables considered for the GLM were year, season, percentage of grassland cover, percentage snow cover and depth, and livestock density. All density values were natural-log transformed. We then conducted a backward removal of variables from the maximized 


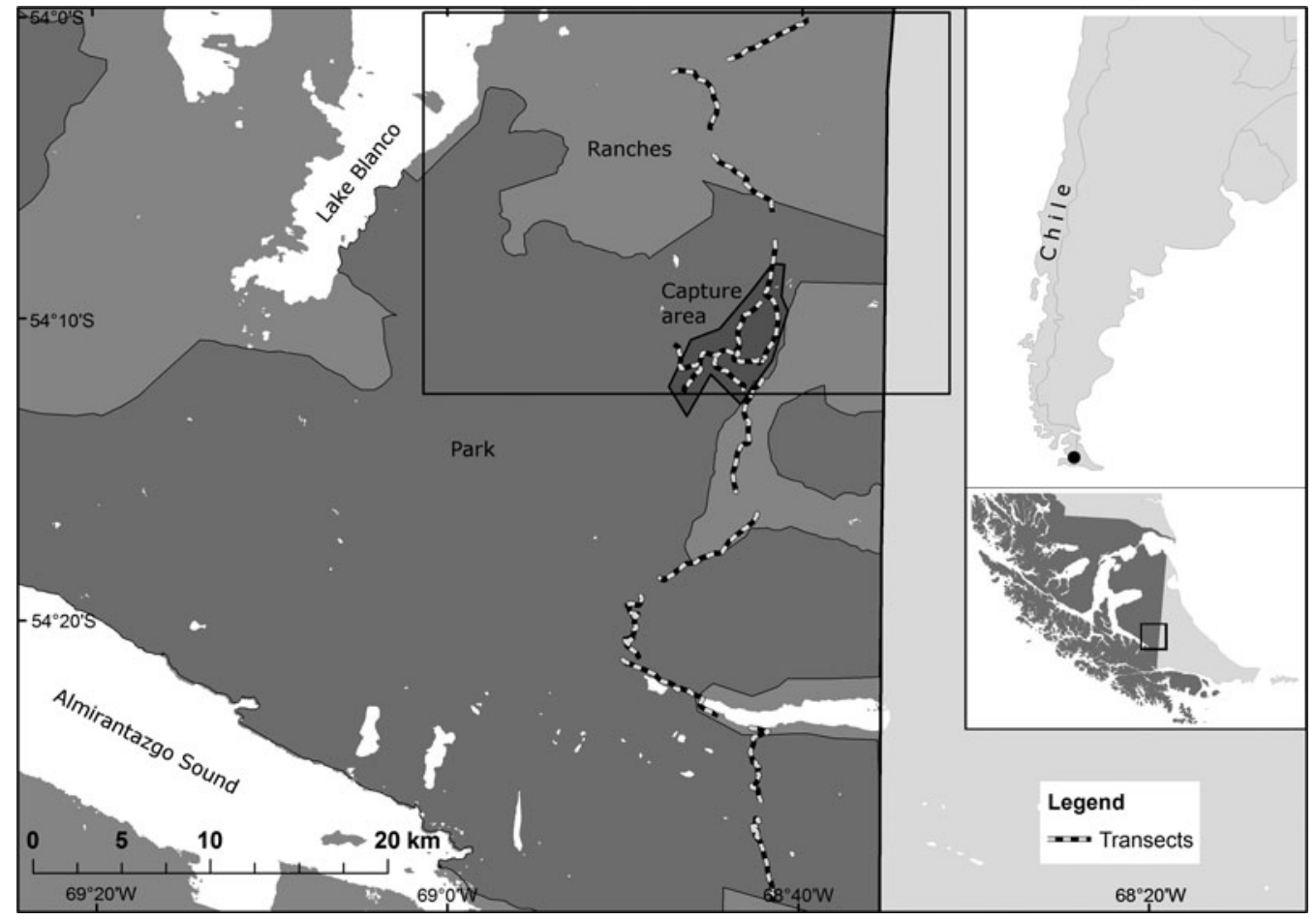

FIG. 1 The location of the study area on Tierra del Fuego Island. The survey transects are shown along with the capture area for guanacos Lama guanicoe that were radio-tracked across open and closed habitats. The rectangle on the bottom inset shows the location of the main map in Chile.

model using $\mathrm{P}=0.05$ to assess which variable was more related to guanaco density. Because high-elevation transects had almost no livestock we also tested the effect of livestock on guanaco density by building a model with data from lowelevation transects, including livestock density, snow depth, and year as independent variables. Both GLM analyses were carried out using Statistica v. 7 (StatSoft, Tulsa, USA).

To examine the processes that led to seasonal changes in guanaco abundance at the landscape scale, we studied guanaco movements and habitat selection at a finer spatial scale using radio-telemetry. Our intensive study area corresponded to the central portion of the altitudinal gradient along the border between Karukinka and the neighbouring ranches. Guanaco social structure includes family and bachelor groups (Franklin, 1983). We investigated primarily the movements of family groups, which are usually territorial. Ten adult guanacos from family groups were captured and radio-collared with VHF transmitters (Advanced Telemetry Systems, Isanti, USA) between January 2007 and January 2008, following capture procedures described in Karesh et al. (1998), and radio-tracked until September 2010. Data for a guanaco that lost its transmitter 2 months after capture were excluded from the analysis. We restricted the capture area (Fig. 1) to maximize the likelihood that guanacos were using a variety of habitats in Karukinka and the adjacent ranches. Telemetry readings were taken during daylight hours. Until July 2009 we confirmed guanaco locations through direct observation whenever possible. After July 2009 we did not confirm locations with direct observations and therefore excluded these locations from habitat-use analyses, utilizing them only to assess shifts between summer and winter ranges (see below). LOAS v. 4.0 (Ecological Software Solutions, Sacramento, USA; Larson, 2001) was used for bearing analyses. To study seasonal movements we divided the telemetry data into summer (November-April) and winter (May-October) to account for key seasonal changes in guanaco social behaviour (Ortega \& Franklin, 1995). To estimate seasonal home-range size and location for each guanaco we generated minimum convex polygons (MCPs) using the Animal Movement v. 2.o extension in ArcView (Hooge \& Eichenlaub, 2000). We then plotted seasonal home-range sizes against number of locations to estimate the minimum number of locations required to achieve stable estimates of home-range size. To quantify seasonal movements we calculated a centroid for each seasonal home range and measured the distance between centroids for each guanaco, using radio-telemetry locations until September 2010, and detected migration when we observed a complete round-trip shift between seasonal home ranges that were not used at other times of the year (Berger, 2004).

For the habitat selection analysis we determined habitat use by assigning each guanaco location to a vegetation type. We determined vegetation types available in four types of 


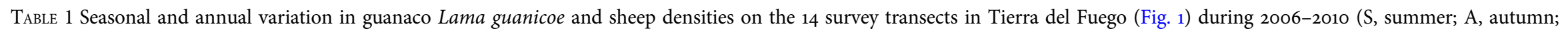
W, winter; P, spring; years are subscripted), with mean percentage grassland and snow cover and mean snow depth.

\begin{tabular}{|c|c|c|c|c|c|c|c|}
\hline \multirow{2}{*}{$\begin{array}{l}\text { Mean transect } \\
\text { altitude } \pm S E(m)\end{array}$} & \multicolumn{2}{|c|}{$\begin{array}{l}\text { Mean guanaco densities } \pm \mathrm{SE} \mathrm{km}^{-2} \\
\text { (no. of groups); seasons } \\
\text { years }\end{array}$} & \multicolumn{2}{|c|}{$\begin{array}{l}\text { Mean sheep densities } \pm \text { SE km } \\
\text { (no. of groups); seasons } s_{\text {years }}\end{array}$} & \multirow{2}{*}{$\begin{array}{l}\text { Grassland } \\
\text { cover }(\%)\end{array}$} & \multirow{2}{*}{$\begin{array}{c}\text { Mean snow } \\
\text { cover } \pm \text { SE } \\
(\%)\end{array}$} & \multirow{2}{*}{$\begin{array}{l}\text { Mean snow } \\
\text { depth } \pm S E \\
(\mathrm{~cm})\end{array}$} \\
\hline & Min & Max & Min & Max & & & \\
\hline $175 \pm 2$ & $2.3 \pm 0.5(3) ; P_{10}$ & $34.8 \pm 5.8(40) ; \mathrm{W}_{07}$ & $\begin{array}{l}0.0 ; S_{08,09,10}, A_{08,09,10}, W_{09,10} \\
P_{09,10}\end{array}$ & $319.3 \pm 188.3(21) ; \mathrm{P}_{06}$ & 82.3 & $37.2 \pm 1.3$ & $9.6 \pm 1.3$ \\
\hline $169 \pm 2$ & $1.0 \pm 0.1(2) ; \mathrm{A}_{10}$ & $21.8 \pm 3.6(25) ; \mathrm{W}_{07}$ & $0.0 ; \mathrm{S}_{10}, \mathrm{~A}_{10}, \mathrm{~W}_{10}, \mathrm{P}_{10}$ & $187.7 \pm 70.8(11) ; \mathrm{A}_{08}$ & 55.3 & $34.2 \pm 0.5$ & $8.1 \pm 1.2$ \\
\hline $167 \pm 2$ & $1.9 \pm 0.3(4) ; \mathrm{A}_{10}$ & $36.9 \pm 3.7(36) ; \mathrm{A}_{08}$ & $8.7 \pm 3.5(6) ; \mathrm{P}_{09}$ & $221.8 \pm 83.7(13) ; \mathrm{A}_{08}$ & 67.0 & $41.7 \pm 2.2$ & $11.8 \pm 1.6$ \\
\hline $163 \pm 1$ & $6.8 \pm 0.9(20) ; \mathrm{W}_{10}$ & $44.7 \pm 6.3(52) ; \mathrm{P}_{06}$ & $\begin{array}{l}0.0 ; \mathrm{S}_{07,08,09,10}, \mathrm{~A}_{08,09,10} \\
\mathrm{~W}_{07,08,09,10}, \mathrm{P}_{06,07,08,09,10}\end{array}$ & $61.6 \pm 23.5(6) ; \mathrm{A}_{07}$ & 86.1 & $45.0 \pm 1.7$ & $11.8 \pm 1.6$ \\
\hline $176 \pm 2$ & $4.8 \pm 0.7(14) ; \mathrm{W}_{10}$ & $37.1 \pm 4.9(55) ; \mathrm{P}_{08}$ & $\begin{array}{l}0.0 ; \mathrm{S}_{07,08,09,10}, \mathrm{~A}_{08,09,10} \\
\mathrm{~W}_{07,08,09,10}, \mathrm{P}_{06,07,08,09,10}\end{array}$ & $123.2 \pm 47(12) ; \mathrm{A}_{07}$ & 70.6 & $52.1 \pm 1.8$ & $16.4 \pm 1.8$ \\
\hline $216 \pm 2$ & $8.2 \pm 1.1(34) ; \mathrm{A}_{08}$ & $50.0 \pm 9.2(30) ; S_{10}$ & * & * & 28.1 & $52.1 \pm 1.3$ & $12.5 \pm 0.7$ \\
\hline $216 \pm 1$ & $3.3 \pm 0.5(12) ; \mathrm{A}_{07}$ & $43.6 \pm 10.8(18) ; S_{07}$ & * & * & 48.7 & $67.1 \pm 1.4$ & $18.2 \pm 0.9$ \\
\hline $211 \pm 1$ & $1.4 \pm 0.3(1) ; \mathrm{P}_{10}$ & $37.1 \pm 6.9(6) ; S_{10}$ & * & * & 21.0 & $66.0 \pm 1.3$ & $15.0 \pm 0.7$ \\
\hline $237 \pm 2$ & $1.5 \pm 0.2(2) ; \mathrm{A}_{08}$ & $26.1 \pm 6.5(6) ; S_{07}$ & * & * & 26.5 & $45.0 \pm 0.4$ & $6.7 \pm 0.8$ \\
\hline $261 \pm 2$ & $0.3 \pm 0.0(4) ; \mathrm{W}_{07}$ & $46.1 \pm 7.2(59) ; \mathrm{P}_{06}$ & * & * & 60.1 & $57.1 \pm 0.4$ & $25.1 \pm 1.9$ \\
\hline $527 \pm 6$ & $0.0 ; A_{08,09} W_{07,09,10}$ & $7.3 \pm 1.5(16) ; \mathrm{S}_{08}$ & * & * & 14.7 & $65.8 \pm 0.5$ & $37.5 \pm 2.1$ \\
\hline $202 \pm 2$ & $0.0 ; S_{06,07} W_{07,09,10} P_{06,07}$ & $0.8 \pm 0.1(3) ; \mathrm{P}_{09}$ & * & * & 17.6 & $62.5 \pm 0.9$ & $40.0 \pm 1.9$ \\
\hline $338 \pm 9$ & $0.0 ; S_{09,10} A_{09} W_{07,09}$ & $3.2 \pm 0.6(7) ; S_{08}$ & * & * & 3.9 & $59.2 \pm 1.4$ & $34.7 \pm 2.3$ \\
\hline $563 \pm 10$ & $0.0 ; A_{08,09} W_{07,09,10}$ & $5.5 \pm 1.1(12) ; \mathrm{S}_{08}$ & * & * & 3.2 & $70.8 \pm 1.4$ & $42.5 \pm 1.6$ \\
\hline
\end{tabular}

${ }^{*}$ No sheep ranching during any survey 
ranges: ranges of sedentary guanacos that remained most of the year in Karukinka, ranges of sedentary guanacos that remained most of the year on the ranches, and winter and summer ranges of migratory guanacos. We plotted four MCPs with all locations in these four guanaco range types and intersected them with the same vegetation map used for the GLM analysis. Using the $\chi^{2}$ statistic, we performed a habitat selection analysis, comparing proportions of locations recorded and expected according to available vegetation cover. When selection was significant, we used Bonferroni confidence intervals to test for differences between use and availability of each habitat. To represent the magnitude of the selection we calculated Manly's standardized selection index $\left(B_{i}\right)$ for each habitat, which is based on subsequently standardized selection ratios (Manly et al., 2002). Standardized ratios provide indices of selection that are directly comparable between seasons. Independence of locations for analyses of home-range size and habitat selection was ensured by obtaining telemetry readings every 4 days (on average), at different times of the day.

\section{Results}

\section{Factors affecting guanaco density}

Guanaco densities averaged $17.2 \mathrm{~km}^{-2}$ in low-elevation transects with abundant grass cover (mean $73.1 \%$ grassland) and sheep grazing throughout the year, $18.6 \mathrm{~km}^{-2}$ in midelevation transects with intermediate grass cover (mean $60.1 \%$ grassland) and limited livestock grazing, and $1.5 \mathrm{~km}^{-2}$ in high-elevation transects with dominant forest cover (mean 75.1\% forest) and no ranching (Table 1). Guanacos were present in high-elevation transects only during spring and summer. Sheep density in low-elevation transects peaked in spring (mean $30.7 \pm \mathrm{SE} 12.0 \mathrm{~km}^{-2}$ ) and autumn (mean $50.5 \pm$ SE $\left.16.7 \mathrm{~km}^{-2}\right)$ and was low in summer $\left(12 \pm \mathrm{SE} 5.1 \mathrm{~km}^{-2}\right)$ and winter $\left(10.7 \pm \mathrm{SE} 4.1 \mathrm{~km}^{-2}\right)$. Mean annual density of cattle was low in the first part of the study $\left(0.2 \pm \mathrm{SE} 0.1 \mathrm{~km}^{-2}\right.$ in 2007 and $0 \mathrm{~km}^{-2}$ in 2008) and increased to $1.9 \pm \mathrm{SE} 1.0 \mathrm{~km}^{-2}$ in 2009 and $8.0 \pm \mathrm{SE} 4.0 \mathrm{~km}^{-2}$ in 2010 . Horse density was stable and averaged $1.2 \pm \mathrm{SE} 0.12 \mathrm{~km}^{-2}$ during the study. Cattle and horses occurred mainly on low-elevation transects.

The model indicated that guanaco densities in the study area were positively associated with grassland cover and negatively associated with snow depth during autumn and winter (Table 2). The analysis that included only transects at low elevation indicated that guanaco density was negatively associated with livestock density (Table 2). There was an overall decline in guanaco density in the area during the study, as indicated by the significant negative effect of year in the GLM. Between 2007 and 2010 mean annual guanaco density across all transects declined by $25.3 \%$. The guanaco decline occurred as sheep numbers declined (78\%) and cattle increased.
TABLE 2 GLM estimates of guanaco densities in Tierra del Fuego (Fig. 1) for all transects and for low-elevation transects only (135$305 \mathrm{~m})$.

\begin{tabular}{lccc}
\hline Effect & Estimate \pm SE & Wald statistic & $\mathrm{P}$ \\
\hline All transects & & & \\
Intercept & $0.35 \pm 0.11$ & 10.21 & 0.001396 \\
Grassland cover & $0.01 \pm 0.00$ & 32.93 & 0.000000 \\
Snow depth & $-0.05 \pm 0.01$ & 23.71 & 0.000001 \\
Scale & $1.00 \pm 0.00$ & & \\
Low-elevation transects only & & \\
Intercept & $108.25 \pm 45.05$ & 5.77 & 0.016264 \\
Year & $-0.05 \pm 0.02$ & 5.66 & 0.017355 \\
Snow depth & $-0.02 \pm 0.01$ & 14.63 & 0.000131 \\
Sheep density & $-0.03 \pm 0.02$ & 5.01 & 0.025188 \\
Cattle density & $-0.08 \pm 0.04$ & 3.95 & 0.046813 \\
Scale & $0.49 \pm 0.00$ & & \\
\hline
\end{tabular}

\section{Guanaco seasonal movements and habitat selection}

All but one (ID 945) of the radio-tracked guanacos were members of family groups. Visual confirmation of group status was obtained on 4-25 occasions per individual (Table 3). From these groups we detected only two migratory guanacos. They were both females (843 and 884) and migrated from Karukinka to sheep ranches in summer and winter, respectively (Table 3, Figs 1 \& 2). These migratory guanacos spent summers in Karukinka as part of family groups (Table 3), and winters either entirely or partially on sheep ranches. Guanaco 843 ranged in winter onto a ranch in neighbouring Argentina with similar land use to Chilean sheep ranches and returned to the 2007 summer home range in the summers of 2008-2010 (Fig. 2). Migratory guanacos expanded their ranges in winter: mean home-range size was 23 times larger in winter (28.28 $\left.\pm \mathrm{SE} 10.76 \mathrm{~km}^{2}, \mathrm{n}=2\right)$ than in summer $\left(1.74 \pm \mathrm{SE} 1.32 \mathrm{~km}^{2}\right.$, $\mathrm{n}=2$; Table 3). Guanaco 884 died at the end of the 2007 winter, when it was moving towards its previous year's summer range (Fig. 2). A necropsy indicated poor nutritional condition (based on marrow fat content) and a widespread sarcoptic mange infection.

Six other radio-tracked guanacos were considered sedentary because they did not make significant shifts between seasonal ranges: mean distance between the centroids of their summer and winter ranges was $1.7 \pm \mathrm{SE} 0.3 \mathrm{~km}$ (Table 3, Fig. 2). Five of the sedentary guanacos were part of family groups every summer. Male guanaco 945 was part of a family group when captured but joined a bachelor group 3 months after capture. Four (three males and one female) of the five sedentary guanacos in family groups had $75-100 \%$ of their home ranges inside Karukinka, whereas the remaining one (male 1123) had $94 \%$ of its range within a neighbouring ranch (Fig. 2). This particular ranch had a high density of sheep (61-123 $\left.\mathrm{km}^{-2}\right)$ only during autumn 2007 and no livestock during the remainder of the study. 
TABLE 3 Home range of the 10 radio-tracked guanacos in Tierra del Fuego (Fig. 1) in successive seasons during January 2007-September 2009, with age and gender, type of social group, mean distance between home-range centroids, number of sightings with social group, period of radio-tracking, size of annual (or summer and winter) home range, and percentage of home range within Karukinka protected area.

\begin{tabular}{|c|c|c|c|c|c|c|c|c|c|}
\hline \multirow[b]{2}{*}{ Guanaco } & \multirow[b]{2}{*}{$\begin{array}{l}\text { Age \& } \\
\text { gender }\end{array}$} & \multirow[b]{2}{*}{$\begin{array}{l}\text { Type of } \\
\text { group }\end{array}$} & \multirow{2}{*}{$\begin{array}{l}\text { Mean distance } \pm \mathrm{SE} \\
\text { between centroids, km } \\
\quad \text { (no. of seasons) }\end{array}$} & \multirow{2}{*}{$\begin{array}{l}\text { No. of } \\
\text { sightings } \\
\text { with group }\end{array}$} & \multirow[b]{2}{*}{$\begin{array}{l}\text { Tracking } \\
\text { period }\end{array}$} & \multicolumn{4}{|c|}{ Home range, $\mathrm{km}^{2}$ (no. of locations) } \\
\hline & & & & & & Annual & Summer & Winter & $\begin{array}{l}\text { \% within } \\
\text { Karukinka }\end{array}$ \\
\hline 1014 & $\begin{array}{l}\text { Adult } \\
\text { male }\end{array}$ & Family & $0.58 \pm 0.18(4)$ & 12 & $\begin{array}{l}\text { Jan. 2008- } \\
\text { June } 2009\end{array}$ & $2.10(22)$ & & & 94 \\
\hline 1045 & $\begin{array}{l}\text { Adult } \\
\text { male }\end{array}$ & Family & $0.57 \pm 0.16(3)$ & 17 & $\begin{array}{l}\text { Jan. 2008- } \\
\text { June } 2009\end{array}$ & $2.07(28)$ & & & 75.1 \\
\hline 1083 & $\begin{array}{l}\text { Adult } \\
\text { male }\end{array}$ & Family & $1.67 \pm 1.12(5)$ & 8 & $\begin{array}{l}\text { Jan. } 2008- \\
\text { June } 2009\end{array}$ & $1.22(25)$ & & & 100 \\
\hline 1123 & $\begin{array}{l}\text { Adult } \\
\text { male }\end{array}$ & Family & $1.31 \pm 0.51(5)$ & 4 & $\begin{array}{l}\text { Jan. 2008- } \\
\text { June } 2009\end{array}$ & $6.08(28)$ & & & 5.9 \\
\hline 1161 & $\begin{array}{l}\text { Young } \\
\text { adult } \\
\text { female }\end{array}$ & Family & $2.66 \pm 1.0(5)$ & 6 & $\begin{array}{l}\text { Jan. } 2008- \\
\text { June } 2009\end{array}$ & $5.67(29)$ & & & 99.7 \\
\hline $945^{1}$ & $\begin{array}{l}\text { Young } \\
\text { adult } \\
\text { male }\end{array}$ & Bachelor & $3.54 \pm 0.48(3)$ & 23 & $\begin{array}{l}\text { Sep. } 2007- \\
\text { June } 2009\end{array}$ & $12.23(24)$ & & & 100 \\
\hline 984 & $\begin{array}{l}\text { Young } \\
\text { adult } \\
\text { female }\end{array}$ & Family & $11.62 \pm 5.34(4)$ & 10 & $\begin{array}{l}\text { Jan. } 2008- \\
\text { Oct. } 2008\end{array}$ & $4.70(18)$ & & & 100 \\
\hline \multirow[t]{3}{*}{843} & $\begin{array}{l}\text { Adult } \\
\text { female }\end{array}$ & $\begin{array}{l}\text { Family } \\
\text { with } \\
\text { chulengo } \\
\text { (calf) }\end{array}$ & $8.87 \pm 2.36(8)$ & 25 & $\begin{array}{l}\text { Jan. 2007- } \\
\text { Oct. } 2007\end{array}$ & & $0.35(27)$ & $39.04(13)$ & 28 \\
\hline & & & & & $\begin{array}{l}\text { Nov. 2007- } \\
\text { Oct. } 2008\end{array}$ & & $0.41(6)$ & $(2)^{3}$ & \\
\hline & & & & & $\begin{array}{l}\text { Nov. } 2008- \\
\text { June } 2009\end{array}$ & & $4.34(8)$ & $(3)^{3}$ & \\
\hline $884^{2}$ & $\begin{array}{l}\text { Young } \\
\text { adult } \\
\text { female }\end{array}$ & $\begin{array}{l}\text { Family with } \\
\text { chulengo } \\
\text { (calf) }\end{array}$ & $6.50(2)$ & 25 & $\begin{array}{l}\text { Jan. 2007- } \\
\text { Aug. } 2007\end{array}$ & & $1.86(20)$ & $17.51(26)$ & 88.5 \\
\hline
\end{tabular}

${ }^{1}$ Bachelor captured in a family group initially

${ }^{2}$ Died during study

${ }^{3}$ Home range not calculated because of small sample size

Annual home range averaged $4.5 \pm \mathrm{SE} 1.3 \mathrm{~km}^{2}$ for sedentary guanacos from family groups and was three times larger for bachelor 945 (Table 3).

Female guanaco 984 behaved as sedentary in the summer and winter of 2008 but in the spring of 2008 moved permanently c. $16 \mathrm{~km}$ to the north-west (Fig. 2). During the summer and winter of 2009 she also behaved as sedentary in her new range, which encompassed Karukinka and an adjacent ranch devoted to logging.

There were significant differences in the proportions of habitats used by migratory guanacos in summer and winter, but not by sedentary guanacos (Table 4). The Bonferroni confidence limits indicated that migratory guanacos used forests less than expected in summer but did not significantly select or avoid any particular habitat during winter (Table 4). Manly's standardized selection index indicated that during summer migratory guanacos selected the small grassland area within Karukinka about five times more often than deciduous forests and four times more often than meadows. Conversely, during winter, when much of the grassland habitat in the ranches was occupied by sheep, migratory guanacos selected meadows about four times more often than grasslands and forests (Table 4).

Migratory guanacos occurred in areas of higher livestock density during winter (mean 46.4 sheep and 2.7 cattle $\mathrm{km}^{-2}$ ), whereas the sedentary guanacos $(1014,1045$ and 1123) used the ranches with few or no livestock after autumn 2007 towards the east of Karukinka (Fig. 2). Although there was no significant habitat selection by sedentary guanacos that lived mostly within Karukinka, in summer they tended to avoid forests (Table 4). 

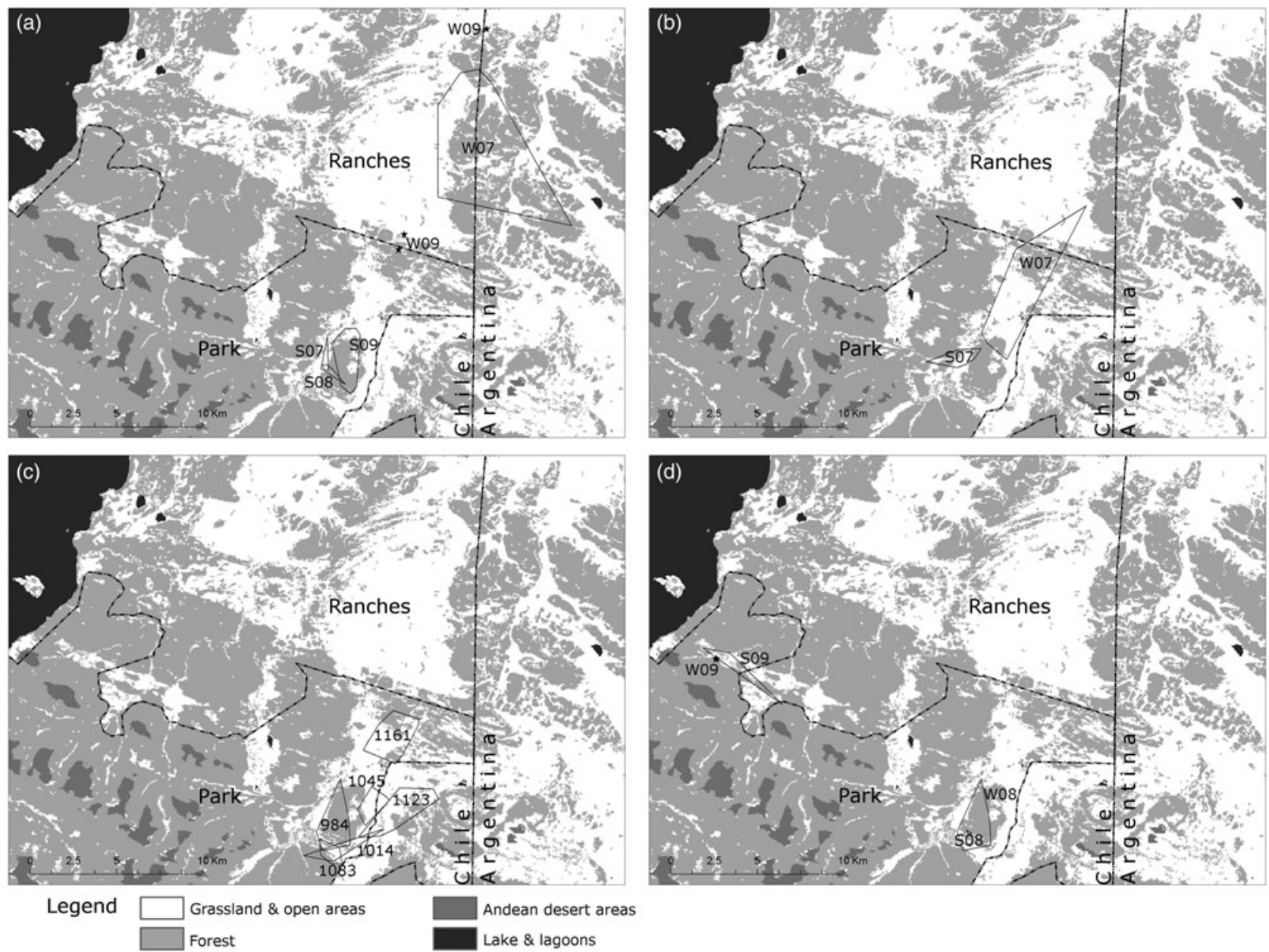

FIG. 2 Seasonal home range of migratory guanacos (843, 884 and 984 in (a), (b) and (d), respectively) and (c) annual home range of sedentary guanacos $(984,1014,1045,1083,1123$ and 1161) followed by radio-tracking in Tierra del Fuego, including minimum convex polygon areas by season (S, summer; W, winter) and year (e.g. Wo7). No winter 2008 data were available for guanaco 843 . The stars in (a) show the positions of guanaco 843 in winter 2009, and the star in (d) shows the last position of guanaco 984 in winter 2009.

\section{Discussion}

Factors affecting guanaco seasonal density

We observed that a large proportion of the guanaco population studied in the forest-grassland mosaic had a preference for grasslands, as reported elsewhere where forests are absent (Puig et al., 2011). Firstly, guanaco density at the landscape scale was highest throughout the year where grassland cover was highest (Tables $1 \& 2$ ). Secondly, guanaco density during summer, when all habitats were available because of the absence of snow, was lowest at high elevations where the proportion of grassland cover was lowest (Table 1). These patterns are consistent with those of other ungulates with mixed diets that inhabit grassland-forest mosaics, such as elk Cervus canadensis, white-tailed deer Odocoileus virginianus and mule deer Odocoileus hemionus hemionus, which at coarse spatial scales prefer open grasslands (Hebblewhite et al., 2008; Massé \& Côté, 2009; Laundré, 2010).
Increases in guanaco density at high elevations during summer and at mid and low elevations during spring and autumn are consistent with altitudinal movements of other mountain-dwelling ungulates that migrate seasonally, such as black-tailed deer Odocoileus hemionus columbianus, elk, and red deer Cervus elaphus (Schoen \& Kirchhoff, 1985; Hebblewhite et al., 2008; Pépin et al., 2008). These increases in guanaco density at high elevations during summer were mostly associated with movement of family groups and solitary guanacos in Karukinka. This relationship between density and elevation has also been observed for guanacos in Torres del Paine National Park during summer (Ortega \& Franklin, 1995; Young \& Franklin, 2004).

Snow depth and cover limited the density of guanacos at high elevations during winter. A similar pattern has been observed at the landscape scale for other mountain ungulates, including the Alpine chamois Rupicapra rupicapra and elk (Boldt \& Ingold, 2005; Hebblewhite et al., 2008). Even at low elevations snow cover and depth during winter 
TABLE 4 Habitat selection by migratory and sedentary radio-tracked guanacos in Tierra del Fuego from January 2007 to July 2009 (habitat preference is shown by the significance of the $\chi^{2}$ test), with the number of locations used, Manly's standardized selection index ( $\mathrm{B}_{\mathrm{i}}$; Manly et al., 2002), the available proportion of each vegetation type, and the proportion of vegetation type used (with $95 \%$ Bonferroni confidence interval).

\begin{tabular}{lcrll}
\hline Vegetation type & No. of locations & $\mathrm{B}_{\mathrm{i}}$ & Available proportion & Proportion used (95\% Bonferroni confidence limits) \\
\hline Migratory, summer $\left(\chi^{2}=19.643, \mathrm{df}=2, \mathrm{P}<\right.$ & $0.001)$ & \\
Grassland/bush/steppe & 8 & 0.65 & 0.038 & $0.140(0.019-0.262)$ \\
Meadow & 21 & 0.22 & 0.294 & $0.368(0.200-0.537)$ \\
Deciduous forest & 28 & 0.13 & 0.668 & $\mathbf{0 . 4 9 1}(\mathbf{0 . 3 1 6 - 0 . 6 6 6 )})$ \\
Migratory, winter $\left(\chi^{2}=15.956, \mathrm{df}=2, \mathrm{P}<0.001\right)$ & & $0.435(0.242-0.628)$ \\
Grassland/bush/steppe & 20 & 0.17 & 0.504 & $0.196(0.041-0.350)$ \\
Meadow & 9 & 0.66 & 0.058 & $0.370(0.182-0.557)$ \\
Deciduous forest & 17 & 0.17 & 0.438 & \\
Sedentary, in Karukinka in summer $\left(\chi^{2}=2.697, \mathrm{df}=2, \mathrm{P}=0.260\right)$ & 0.513 \\
Grassland/bush/steppe & 20 & 0.40 & 0.416 & 0.231 \\
Meadow & 9 & 0.38 & 0.200 & 0.256 \\
Deciduous forest & 10 & 0.22 & 0.383 & \\
Sedentary, in Karukinka in winter $\left(\chi^{2}=2.663, \mathrm{df}=2, \mathrm{P}=0.264\right)$ & 0.411 \\
Grassland/bush/steppe & 39 & 0.32 & 0.416 & 0.221 \\
Meadow & 21 & 0.36 & 0.200 & 0.368 \\
Deciduous forest & 35 & 0.31 & 0.383 & \\
Sedentary, outside Karukinka $\left(\chi^{2}=3.942648, \mathrm{df}=2, \mathrm{P}=0.139\right)$ & 0.607 \\
Grassland/bush/steppe & 17 & 0.49 & 0.439 & 0.250 \\
Meadow & 7 & 0.33 & 0.270 & 0.143 \\
Deciduous forest & 4 & 0.18 & 0.291 & \\
\hline
\end{tabular}

*Vegetation type is used significantly less (value in bold) if the available proportion is larger than the upper limit of the Bonferroni confidence interval of proportion used $(\mathrm{P}<0.05)$.

affected guanaco habitat use; we often observed guanacos feeding on sun-facing slopes where they were more likely to find snow-free patches, as occurs with the Alpine chamois (Boldt \& Ingold, 2005). Ortega \& Franklin (1995) suggested that guanaco migration is related to snow accumulation in highland areas, which may cause a severe reduction of available forage in winter and trigger migration. The same relationship between snow accumulation and migration appears to be common among other migratory mountain ungulates (Schoen \& Kirchhoff, 1990; Boldt \& Ingold, 2005; Hebblewhite et al., 2008; White et al., 2010).

The negative relationship between guanaco and sheep densities at low elevations (Table 2) confirms the effect of sheep on guanacos (Raedeke, 1982; Baldi et al., 2001). At the landscape scale wild herbivores that coexist with livestock tend to suffer density declines throughout the area of overlap or concentrate in areas that are free from livestock, as in the case of chital Axis axis, gaur Bos gaurus, and Asian elephant Elephas maximus (Madhusudan, 2004). At the habitat scale, on the other hand, wild herbivores such as elk and mule deer also display strategies that include temporal avoidance of livestock (Stewart et al., 2002). Because of the regular patrols by rangers it was unlikely that guanacos suffered direct persecution by poachers in Karukinka. Some level of persecution, however, occurred outside Karukinka, as evidenced by the short flightdistances observed on the ranches (C.A. Moraga et al., unpubl. data) and killing of guanaco 1045 by poachers in 2010.

The decline of guanacos that we recorded may be a consequence of overgrazing by sheep as a result of decades of poor range management. Range condition was already poor on the ranches around Karukinka in the late 1970s as a consequence of overgrazing (Lara \& Cruz, 1987). Between 2007 and 2009 there was a high density of sheep and they were moved little among paddocks in the largest ranch neighbouring Karukinka, leading to high mortality of ewes and lambs (C.A. Moraga, unpubl. data). In June 2010 the ranch manager was replaced and most remaining sheep were removed but range condition was already poor. Poor range management, with negative demographic effects on sheep, explains the region-wide decline in range productivity and the collapse of the number of sheep in Patagonia (Aagesen, 2000; Texeira \& Paruelo, 2006).

\section{Seasonal movement patterns and habitat selection}

Our study confirms the persistence of seasonal migration in the guanacos of Tierra del Fuego, and also that part of the population is sedentary, as proposed by Raedeke (1982). This mixed movement pattern has also been described for moose Alces alces and elk (Ball et al., 2001; Hebblewhite et al., 2008).

The home-range sizes of the migratory guanacos in Karukinka were as small as in Torres del Paine National 
Park during summer (Young \& Franklin, 2004). Defence of territories by dominant males from family groups during the reproductive season, in addition to greater availability of good-quality forage, may explain the reduced size of summer ranges (Ortega \& Franklin, 1995). Similar to migrants, sedentary guanacos in our study used larger areas in winter compared to summer (C.A. Moraga, unpubl. data). The death by starvation in late winter of migrant 884 , however, suggests that an increase in its home-range size was not sufficient to compensate for reduced winter forage where the range was shared with abundant sheep. Differences in forage quality and quantity between summer and winter probably contributed to the differences in seasonal home-range sizes of guanacos as they did for roe deer Capreolus capreolus and white-tailed deer (Mysterud, 1999; Lesage et al., 2000).

The five radio-tracked males in our study were all sedentary. Young \& Franklin (2004) suggested that males establish and defend territories for as long as they can, which may explain the sedentary behaviour of males that we captured and radio-collared while they held family groups (Sarno et al., 2003), with the exception of male 945. This guanaco displayed the typical transition from family to bachelor group described for juvenile guanacos in Torres del Paine Park (Young \& Franklin, 2004). Females, on the other hand, are expected to display lower site fidelity than males after the reproductive season (Jurgensen, 1985). Accordingly, females 884 and 843 migrated seasonally and returned to previously occupied ranges the following year but female 1161 was sedentary throughout the year. Female 984 left the range used during the first year, although this probably represented expulsion from a family group and dispersal into a new range (Sarno et al., 2003). Both guanacos that appeared to have been expelled from their original family groups were classified as young adults when they were captured and collared (Table 3).

All the guanacos radio-tracked in our study utilized the forest but none selected this habitat type over others. Specifically, reduced utilization of forests in summer by migrants and by sedentary guanacos in Karukinka suggests that forests were not a high-quality habitat for guanacos during the reproductive season. Conversely, meadows appeared to be important habitats for migratory guanacos during winter, a preference reported for guanacos in areas of the high Andes and southern Patagonia during summer (Bank et al., 2003; Puig et al., 2011). Meadows in Tierra del Fuego are highly productive habitats that are important for sheep during summer (Cingolani et al., 1998). As we observed, meadows were not heavily utilized by sheep in winter, perhaps as a result of the high humidity and the formation of ponds. The concentration of sheep in grasslands during winter may have forced guanacos to use the wetter meadows as a second-best choice after grasslands.

\section{Conservation implications}

The interaction between guanacos and forests is a contentious issue in Tierra de Fuego (Martínez-Pastur et al., 1999; Skewes et al., 1999; Cavieres \& Fajardo, 2005). Our study provides the first quantitative information on the effect of sheep ranching on guanaco density and use of forest habitats, a key factor in the conflict between logging, ranching, and wildlife in Tierra del Fuego. Based on Raedeke's (1979) seasonal counts and our study, migratory guanacos that move to grassland-dominated lower elevations in autumn and winter may face competition from livestock. Migratory guanacos had higher mortality from starvation than sedentary guanacos (Raedeke, 1979), although this was not confirmed by studying marked individuals. However, the timing and condition at death of migratory guanaco 884 , as well as the negative effect of sheep on guanaco numbers, may support Raedeke's conclusion. If migratory guanacos that use predominantly forested areas such as Karukinka and properties devoted to logging in summer face high nutritional stress during winter, then adjustments in levels and timing of livestock stocking rates in neighbouring areas may be needed to recover the range and also maintain seasonal use by guanacos, particularly in winter. Ultimately, high sheep densities and range degradation on ranches appears to be detrimental to logging interests as well as to guanacos, as they exacerbate guanaco use of forest habitats.

The Chilean government has authorized six harvests in the southern area of Tierra del Fuego since 2004, with a total of c. 14,700 guanacos harvested. In the last 3 years the logging company in the area has leased the harvest of guanaco for sustainable use. Nonetheless, aiming only for sustainable use may not necessarily favour a reduction of forest browsing by guanaco. For example, hunting guanacos during winter in the forest-grassland mosaic may not be targeting the guanacos that establish range in the logging areas during the growing season. In addition, hunting of easier targets in open areas could encourage surviving guanacos to move inside forests, as human harassment can modify guanaco behaviour and increase their use of marginal habitats (Donadio \& Buskirk, 2006). Hence, current guanaco management by loggers may increase forest use, and may have unexpected negative effects on guanacos and on forests unless it takes into consideration the spatial ecology and habitat requirements of the guanaco.

The guanaco-forest interaction in Tierra del Fuego has been studied exclusively at a local, patch-level scale (Martínez-Pastur et al., 1999; Pulido et al., 200o; Cavieres \& Fajardo, 2005). In particular, the intensive use by guanacos of recently logged forest patches affects the logging industry because browsing significantly slows tree growth and reduces seedling density (Martínez-Pastur et al., 1999; Pulido et al., 2000; Riveros, 2004; Collado et al., 2008). 
Interactions between ungulates and forests that are relevant for forest dynamics, however, must be assessed and managed at both local and landscape scales, as suggested for whitetailed deer in North America (Wisdom et al., 2006; Tremblay et al., 2007; Rutherford \& Schmitz, 2010). Our data provide insight into the interactions among guanacos, forests and sheep ranching, and can be used to guide the assessment of the effects of guanacos at the landscape scale and the management and monitoring of guanaco populations.

The Chilean authorities hope that the sale of guanaco meat from legal harvests will be viewed as a contribution to the economy of the Magallanes region. This value may not be perceived, however, by most of the land owners that sustain the guanaco population. Tierra del Fuego ranchers have shown little interest in sustainably managing guanacos and complaints from the forestry sector have not declined since the legal harvest was initiated. Clearly, integrated management of grasslands, forests and wildlife is needed and it can only be successful if it is implemented at the landscape scale. Integrated management in this case requires combining knowledge of forest dynamics, guanaco spatial and trophic requirements, and livestock and range management, and the interactions among these. Harvesting guanacos may be a useful tool to promote guanaco conservation in parts of Tierra del Fuego but it should be part of an integrated management strategy and it must allow maintenance of key ecological processes such as seasonal migration between forests and grasslands. Ultimately, conservation of Fuegian ecosystems depends on reconciling the interests of livestock husbandry, guanaco conservation and the timber industry.

\section{Acknowledgements}

We thank M. Uhart and C. Marull from the Global Health Program of the Wildlife Conservation Society for their help in capturing guanacos, and B. Saavedra, R. Muza, J. Sotomayor, M. Chacón, C. Silva, D. Droguett, F. Repetto, M. Millán, S. Lorca, J. Gómez, A. Muñoz, A. González, students and Karukinka staff for support. We also thank W. Franklin and an anonymous reviewer for their comments. Permits No. 150 and 4146 were obtained from the Servicio Agrícola y Ganadero-Government of Chile for guanaco captures, and protocols of the Global Health Program of the Wildlife Conservation Society were followed for animal handling. Funding was provided by the Wildlife Conservation Society.

\section{References}

Aagesen, D. (200o) Crisis and conservation at the end of the world: sheep ranching in Argentine Patagonia. Environmental Conservation, 27, 208-215.
Baldi, R., Albon, S.D. \& Elston, D.A. (2001) Guanacos and sheep: evidence for continuing competition in arid Patagonia. Oecologia, 129, 561-570.

Baldi, R., Pelliza-Sbriller, A., Elston, D.A. \& Albon, S.D. (2004) High potential for competition between guanacos and sheep in Patagonia. The Journal of Wildlife Management, 68, 924-938.

Ball, J.P., Nordengren, C. \& Wallin, K. (2001) Partial migration by large ungulates: characteristics of seasonal moose Alces alces ranges in northern Sweden. Wildlife Biology, 7, 39-47.

BANK, M.S., SARNO, R.J. \& FRANKLIN, W.L. (2003) Spatial distribution of guanaco mating sites in southern Chile: conservation implications. Biological Conservation, 112, 427-434.

Berger, J. (2004) The last mile: how to sustain long-distance migration in mammals. Conservation Biology, 18, 320-331.

BoldT, A. \& IngOLD, P. (2005) Effects of air traffic, snow cover and weather on altitudinal short-term and medium-term movements of female Alpine chamois Rupicapra rupicapra in winter. Wildlife Biology, 11, 351-362.

Bolger, D.T., Newmark, W.D., Morrison, T.A. \& Doak, D.F. (2008) The need for integrative approaches to understand and conserve migratory ungulates. Ecology Letters, 11, 63-77.

Bridges, E.L. (1948) Uttermost Part of the Earth. Holder and Stoughton, London, UK.

Buckland, S.T., Anderson, D.R., Burnham, K.P., LaAke, J.L., Borchers, D.L. \& Thomas, L. (2001) Introduction to Distance Sampling: Estimating Abundance of Biological Populations, 2nd edition. Oxford University Press, New York, USA.

Cavieres, L.A. \& Fajardo, A. (2005) Browsing by guanaco (Lama guanicoe) on Nothofagus pumilio forest gaps in Tierra del Fuego, Chile. Forest Ecology and Management, 204, 237-248.

Cingolani, A.M., Anchorena, J. \& Collantes, M.B. (1998) Landscape heterogeneity and long-term animal production in Tierra del Fuego. Journal of Range Management, 51, 79-87.

Collado, L., Farina, S., Jaras, F. \& Vargas, H. (2008) Monitoreo del estado de intervención y de la regeneración de Nothofagus pumilio en un plan de manejo forestal en el ecotono estepa-bosque de Tierra del Fuego, Argentina. Bosque, 29, 85-90.

CONAMA (2009) Ficha de antecedentes de especie Lama guanicoe (Miller, 1776). Reglamento de Clasificación de Especies Silvestres, 5to proceso de clasificación. Ministerio del Medio Ambiente, Gobierno de Chile. Http://www.mma.gob.cl/clasificacionespecies/ficha5proceso/ fichas_actualizadas/Lama_guanicoe_Po5R7-9_RCE.doc [accessed 25 March 2011].

De LA Tour, G.D. (1954) The guanaco. Oryx, 2, 273-279.

Dobson, A.J. (2002) An Introduction to Generalized Linear Models, and edition. Chapman \& Hall/CRC, Boca Raton, USA.

DodDs, P. (1997) Efecto del ramoneo de guanacos (Lama guanicoe) sobre la regeneración de lenga (Nothofagus pumilio) en Russffin, Tierra del Fuego. Forestry thesis. Universidad de Chile, Santiago, Chile.

DonAdio, E. \& BUSKIRK, S.W. (2006) Flight behavior in guanacos and vicuñas in areas with and without poaching in western Argentina. Biological Conservation, 127, 139-145.

Donoso, C. \& Lara, A. (1996) Utilización de los bosques nativos en Chile: pasado, presente y futuro. In Ecología de los bosques nativos de Chile (eds J.J. Armesto, C. Villagrán \& M. Kalin Arroyo), pp. 363387. Editorial Universitaria, Santiago, Chile.

FrankLin, W.L. (1983) Contrasting socioecologies of South America's wild camelids: the vicuña and the guanaco. In Advances in the Study of Mammalian Behavior (eds J.F. Eisenberg \& D. Kleiman), pp. 573-629. American Society of Mammalogists, Shippensburg, USA.

GORDON, I.J. (2009) What is the future for wild, large herbivores in human-modified agricultural landscapes? Wildlife Biology, 15, 1-9. 
Graham, R.T., Jain, T.B. \& Kingery, J.L. (2010) Ameliorating conflicts among deer, elk, cattle and/or other ungulates and other forest uses: a synthesis. Forestry, 83, 245-255.

Harris, G., Thirgood, S., Hopcraft, J.G.C., Cromsigt, J.P.G.M. \& BERgER, J. (2009) Global decline in aggregated migrations of large terrestrial mammals. Endangered Species Research, 7, 55-76.

Hebblewhite, M., Merrill, E. \& McDermid, G. (2008) A multi-scale test of the forage maturation hypothesis in a partially migratory ungulate population. Ecological Monographs, 78, 141-166.

Hooge, P. N. \& Eichenlaub, B. (200o) Animal Movement Extension to ArcView. Version 2.o. Alaska Science Center, Biological Science Office, U.S. Geological Survey, Anchorage, USA.

Huber, U.M. \& MARKGraf, V. (2003) European impact on fire regimes and vegetation dynamics at the steppe-forest ecotone of southern Patagonia. The Holocene, 13, 567-579.

Jurgensen, T.E. (1985) Seasonal territoriality in a migratory guanaco population. MSc thesis. Iowa State University, Ames, USA.

Karesh, W.B., Uhart, M.M., Dierenfeld, E.S., Braselton, W.E., Torres, A., House, C. et al. (1998) Health evaluation of free-ranging guanaco (Lama guanicoe). Journal of Zoo and Wildlife Medicine, 29, 134-141.

LARA, A. \& Cruz, G. (1987) Vegetación del área de uso agropecuario de la XII Región, Magallanes y la Antártica Chilena. INIA (Instituto de Investigaciones Agropecuarias), Santiago, Chile.

LARSON, M.A. (2001) A catalog of software to analyze radiotelemetry data. In Radio Tracking and Animal Populations (eds J.J. Millspaugh \& J.M. Marzluff), pp. 397-421. Academic Press, San Diego, USA.

LAUNDRÉ, J.W. (2010) Behavioral response races, predator-prey shell games, ecology of fear, and patch use of pumas and their ungulate prey. Ecology, 91, 2995-3007.

Lesage, L., Crête, M., Huot, J., Dumont, A. \& Ouellet, J.-P. (200o) Seasonal home range size and philopatry in two northern whitetailed deer populations. Canadian Journal of Zoology, 78, 1930-1940.

Madhusudan, M.D. (2004) Recovery of wild large herbivores following livestock decline in a tropical Indian wildlife reserve. Journal of Applied Ecology, 41, 858-869.

Manly, B.F.J., McDonald, L.L., Thomas, D.L., McDonald, T.L. \& Erickson, W.P. (2002) Resource Selection by Animals: Statistical Design and Analysis for Field Studies, and edition. Kluwer, Boston, USA.

Martínez-Pastur, G., Peri, P.L., Fernández, M.C., Staffieri, G. \& Rodríguez, D. (1999) Desarrollo de la regeneración a lo largo del ciclo del manejo forestal de un bosque de Nothofagus pumilo: 2. Incidencia del ramoneo de Lama guanicoe. Bosque, 20, 47-53.

Martinic, M. (1992) Expansión colonizadora. In Historia de la Región Magallánica, Volume I (ed. M. Martinic), pp. 598-678. Editorial Universidad de Magallanes, Punta Arenas, Chile.

Massé, A. \& Côté, S.D. (2009) Habitat selection of a large herbivore at high density and without predation: trade-off between forage and cover? Journal of Mammalogy, 90, 961-970.

Mysterud, A. (1999) Seasonal migration pattern and home range of roe deer (Capreolus capreoulus) in an altitudinal gradient in southern Norway. Journal of Zoology, 247, 479-486.

Ortega, I.M. \& Franklin, W.L. (1995) Social organization, distribution and movements of a migratory guanaco population in the Chilean Patagonia. Revista Chilena de Historia Natural, 68, 489-500.

Pépin, D., Adrados, C., Janeau, G., Joachim, J. \& Mann, C. (2008) Individual variation in migratory and exploratory movements and habitat use by adult red deer (Cervus elaphus L.) in a mountainous temperate forest. Ecological Research, 23, 1005-1013.

Pisano, E. (1977) Fitogeografía de Fuego-Patagonia chilena. I: Comunidades vegetales entre las latitudes $52^{\circ}$ y $56^{\circ} \mathrm{S}$. Anales del Instituto de la Patagonia, 8, 121-250.
Puig, S., Rosi, M.I., Videla, F. \& Mendez, E. (2011) Summer and winter diet of the guanaco and food availability for a High Andean migratory population (Mendoza, Argentina). Mammalian Biology, 76, 727-734.

Pulido, F.J., Díaz, B. \& Martínez-Pastur, G. (200o) Incidencia del ramoneo del guanaco (Lama guanicoe Muller) sobre la regeneración temprana en bosques de lenga (Nothofagus pumilio (Poepp et Endl) Krasser) de Tierra del Fuego Argentina. Investigación Agraria de Sistemas y Recursos Forestales, 9, 381-394.

Raedeke, K. (1979) Population dynamics and socio-ecology of the guanaco (Lama guanicoe) of Magallanes, Chile. PhD thesis. University of Washington, Seattle, USA.

RAEDEKe, K. (1982) Habitat use by guanacos (Lama guanicoe) and sheep on common range, Tierra del Fuego, Chile. Turrialba, 32, 309314.

Rebertus, A.J., Kitzberger, T., Veblen, T.T. \& Roovers, L.M. (1997) Blowdown history and landscape patterns in the Andes of Tierra del Fuego, Argentina. Ecology, 78, 678-692.

Riveros, J.C. (2004) Efecto del cerco de exclusión de guanacos (Lama guanicoe Müller) sobre el ramoneo en la regeneración de lenga (Nothofagus pumilio (Poepp. et Endl.)), 5 años después de su establecimiento en Russfin, Tierra del Fuego. Memoria de Ingeniería Forestal. Universidad de Chile, Santiago, Chile.

Rutherford, A.C. \& Schmitz, O.J. (2010) Regional-scale assessment of deer impacts on vegetation within Western Connecticut, USA. The Journal of Wildlife Management, 74, 1257-1263.

Safvedra, B., Simonetti, J.A. \& Redford, K.H. (2011) Private conservation, the example that the Wildlife Conservation Society builds from Tierra del Fuego. In Biodiversity Conservation in the Americas: Lessons and Policy Recommendations (ed. E.B. Figueroa), pp. 357-392. Editorial FEN-Universidad de Chile, Santiago, Chile.

Sarno, R.J., Bank, M.S., Stern, H.S. \& Franklin, W.L. (2003) Forced dispersal of juvenile guanacos (Lama guanicoe): causes, variation, and fates of individuals dispersing at different times. Behavioral Ecology and Sociobiology, 54, 22-29.

Sarno, R.J., Franklin, W.L., O’Brien, S.J. \& Johnson, W.E. (2001) Patterns of mtDNA and microsatellite variation in an island and mainland population of guanacos in southern Chile. Animal Conservation, 4, 93-101.

Schoen, J.W. \& Kirchhoff, M.D. (1985) Seasonal distribution and home-range patterns of sitka black-tailed deer on Admiralty Island, southeast Alaska. The Journal of Wildlife Management, 49, 96-103.

Schoen, J.W. \& Kirchhoff, M.D. (1990) Seasonal habitat use by sitka black-tailed deer on Admiralty Island, Alaska. The Journal of Wildlife Management, 54, 371-378.

Skewes, O., Gonzalez, F., Ovalle, C., Rubilar, L., Quezada., M., Jiménez, A. et al. (1999) Manejo Productivo y Sustentable del Guanaco en Isla de Tierra del Fuego. Informe Final (Etapas II y III) Universidad de Concepción, Servicio de Gobierno Regional XII Región, Magallanes y Antártica Chilena, Chillán, Chile.

Stewart, K.M., Bowyer, R.T., Kie, J.G., Cimon, N.J. \& Johnson, B. K. (2002) Temporospatial distributions of elk, mule deer, and cattle: resource partitioning and competitive displacement. Journal of Mammalogy, 83, 229-244.

Texeira, M. \& Paruelo, J.M. (2006) Demography, population dynamics and sustainability of the Patagonian sheep flocks. Agricultural Systems, 87, 123-146.

Thomas, L., Laake, J.L., Rexstad, E., Strindberg, S., Marques, F. F.C., BuCKLAnd, S.T. et al. (2009) Distance 6.o. Release 2. Research Unit for Wildlife Population Assessment, University of St Andrews, UK. Http://www.ruwpa.st-and.ac.uk/distance/ [accessed 31 August 2009]. 
Tremblay, J.-P., Huot, J. \& Potvin, F. (2007) Density-related effects of deer browsing on the regeneration dynamics of boreal forests. Journal of Applied Ecology, 44, 552-562.

Tuhkanen, S., Kuokka, I., Hyvönen, S., Stenroos, S. \& Niemelë, J. (1999) Tierra del Fuego as a target for biogeographical research in the past and present. Anales del Instituto de la Patagonia, 19, $4-107$.

WCS (Wildlife Conservation Society) (2006) Land cover map of Tierra del Fuego, Global Land Cover Facility Landsat 2002 Dataset. Wildlife Conservation Society, Living Landscapes Program and Chile Program, Santiago, Chile.

White, P. J., Proffitt, K.M., Mech, L.D., Evans, S.B., Cunningham, J.A. \& Hamlin, K.L. (2010) Migration of northern Yellowstone elk: implications of spatial structuring. Journal of Mammalogy, 91, 827-837.

Wisdom, M.J., Vavra, M., Boyd, J.M., Hemstrom, M.A., Ager, A. A. \& Johnson, B.K. (2006) Understanding ungulate herbivoryepisodic disturbance effects on vegetation dynamics: knowledge gaps and management needs. Wildlife Society Bulletin, 34, $283-292$.
YounG, J.K. \& FRANKLIN, W.L. (2004) Territorial fidelity of male guanacos in the Patagonia of southern Chile. Journal of Mammalogy, 85, 72-78.

\section{Biographical sketches}

Claudio Moraga's research interests are wildlife ecology and integrative conservation. He is currently studying guanaco-ranching interactions in Southern Patagonia. MARTín Funes's research focuses on carnivore and raptor ecology, exotic species ecology, monitoring techniques, and threats to wildlife in Patagonia. Cristóbal Pizarro's research focuses on human dimensions of wildlife conservation and environmental education. He is currently studying human-bird relationships in North America. CRISTÓBAL BRICEÑO is interested in the conservation and health of threatened wildlife and their habitats, especially those confined to islands. ANDRÉs NOVARO's research focuses on the impacts of hunting on wildlife and predator-prey interactions. He works with governments and the private sector to address threats from extractive industries, livestock grazing and poaching. 